\title{
Subdural hematoma
}

Laura Grace Weldon

Neurology ${ }^{\circledR}$ 2018;90:855. doi:10.1212/WNL.0000000000005411

Thank you Dr. Gandhivarma Subramaniam

Squeezed into pain's tight grip,

my son finally agrees to an ER visit, where

images of his brain's convoluted architecture

show it pushed aside

by blood's gleaming fist.

Seated in waiting room furniture

thickly layered with other people's prayers,

we pass time knuckled, blank

while neurosurgeons saw open his skull.

I think of the girl who fell

10,000 feet from a broken plane

into Peru's jungle. Tightly clustered trees

cushioned her, their limbs breaking

to set her on the forest floor

still safely strapped in her seat.

Wearing white sandals,

a frilly dress

she walked along a stream 11 days

to find rescuers. At first, those men

feared she might be a river ghost.

I want to strap my own son in

so miraculous a seat.

Drop him in a current

where time rushes backward,

before a guy late for his shift

at a donut shop

makes an illegal left turn,

before my son's helmet hits the car,

before my son's body

skids down the pavement,

before vessels begin leaking

into the dear familiar head

I first glimpsed in the birthing room.

Benjamin wakes, blue eyes watery

against ghostly pale skin,

map of a dark river

etched deep across his forehead.

He turns to us, jesting

"No drain bramage!"

to let us know

he's out of the jungle.

\section{Correspondence}

Laura Grace Weldon

laura.euphoria@gmail.com

\section{MORE ONLINE}

ค Audio

Listen to L.G. Weldon

read this poem, available

on the $\mathrm{iPad}^{\circledR}$ and

Android $^{\mathrm{TM}}$ devices.

NPub.org/cwm96d 


\section{Neurology}

\section{Subdural hematoma}

Laura Grace Weldon

Neurology 2018;90;855

DOI 10.1212/WNL.0000000000005411

\section{This information is current as of April 30, 2018}

\section{Updated Information \&} Services

\section{Subspecialty Collections}

Permissions \& Licensing

\section{Reprints}

including high resolution figures, can be found at: http://n.neurology.org/content/90/18/855.full

This article, along with others on similar topics, appears in the following collection(s):

\section{Brain trauma}

http://n.neurology.org/cgi/collection/brain_trauma

Information about reproducing this article in parts (figures,tables) or in its entirety can be found online at:

http://www.neurology.org/about/about_the_journal\#permissions

Information about ordering reprints can be found online:

http://n.neurology.org/subscribers/advertise

Neurology ${ }^{\circledR}$ is the official journal of the American Academy of Neurology. Published continuously since 1951, it is now a weekly with 48 issues per year. Copyright () 2018 American Academy of Neurology. All rights reserved. Print ISSN: 0028-3878. Online ISSN: 1526-632X.

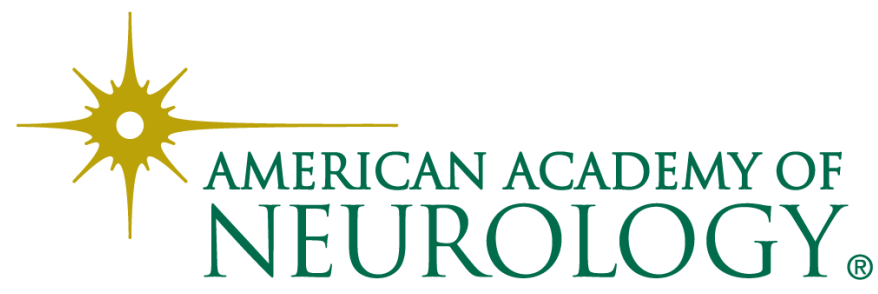

